\title{
Images of the Internet Concept Generated by Primary School Students through Their Paintings*
}

\author{
Necmi Esgi \\ Vildan Cevik \\ Gaziosmanpasa University, Turkey
}

\begin{abstract}
This study investigated primary education students' perception of the Internet through resorting to the images they produced for the Internet concept. Sixty five primary education students constituted the sample of the study. Participants were asked to draw a picture concerning the Internet concept. In addition, researchers gave a 10-item survey form to voluntary students to collect demographic information. Frequency, percentage and Chisquare analyses were carried out for the demographic data collected. Qualitative analyses were conducted on the pictures students drew, and an evaluation chart was prepared. The images that students generated concerning Internet concepts have been categorized as: "game, homework, chat, research, music, video, violence and news". Furthermore, other remarkable themes were torch, individualism, motionlessness and so on. Most common reasons of using the Internet were homework and games. It was revealed that personal Internet usage coincided with the images created concerning the Internet. There appeared a direct connection with the first three objects which came to mind about the Internet and the images they produced.
\end{abstract}

Keywords: Students of Primary Education; Internet; Perception; Painting; Images

\section{Introduction}

"Painting is just another way of keeping a diary."

Pablo Picasso

As an indispensable part of individuals' lives, the Internet has opened the gates of a new world for children in addition to providing families and children with new possibilities and experiences (Orhan \& Akkoyunlu, 2004). In such a new world, various technologies, media and applications have surrounded individuals and provided them with an "imaginary space", which have many digital screens on its walls, just like Plato's "world of ideas". Fast flowing images, pictures, sounds, videos, simulations and social mediums on screens (computer, cell phone, TV, portable media

\footnotetext{
* This study was presented at the $1^{\text {st }}$ National Primary Education Congress organized by Hacettepe University, Turkey.
} 
player, etc.) have been gradually absorbing members of "the screen generation" that transformed from "homo sapiens" to "homo mobilis" in this journey. Mediating the relationship of individuals with surrounding technologies, screens have become more and more sophisticated not only in terms of the things that can be done, and the content; but also in terms of the texture and details (Burnett, 2007). According to Burnett (2007), images-worlds that shape people and their shared environment are supplied to us in the form of complicated interaction groups through various interfaces. These screens are continuously sending messages to our minds everywhere -in the subway, on the street, at home, in the school-, and are represented in our perceptions through our sense organs. These representations form "mental images" by entering our memory through various coding processes (Forrester, 2000).

It would be plausible to clarify the concept of an image at the inception of the theoretical framework. An "image" is defined in the Oxford dictionary as "a representation of the external form of a person or thing in art". In the context of the Internet, multiple-layer web pages, advertisements, pop-ups and banners convey their messages through "images". Before entering our perception, these images are all external. After being coded, they turn into internal images (Forrester, 2002). The internal images determine our point of view about certain facts and contexts, our idea about a subject and our perception of a situation (Forrester, 2000). Then, how do our students perceive this huge virtual network surrounded by these images? What are the images they produced concerning the Internet concept? In order to find the answers to these questions, the current research investigated the perceptions of students - without carrying out a psychological evaluation or analyses - concerning the Internet concept, through paintings produced by $5^{\text {th }}, 6^{\text {th }}$ and $7^{\text {th }}$ graders using "imagery".

Imagery means the depiction of a phenomenon created in mind, which is one of the cognitive processes experienced by any individual (Birch, 2008). Imagery may be in various shapes including similes, metaphors and wordplay (Wikipedia, 2008). Similes are often introduced with the words "like, as" to compare different ideas or things. Metaphors are similar to similes, but the words "like, as" are not employed. Metaphor is a tool of perception (Arnett, 1999). Metaphoric ideas use similar events and objects in order to explain the characteristics of complex phenomena and situations (Oxford, Tomlinson, Barcelos, Harrington, Lavine \& Saleh, 1998). According to Morgan (1998), metaphors are ways of thought and sight (cited in Cerit, 2006). They involve the narration of an unknown event or situation through using the known event and situations. Likewise, according to Lakoff and Johnson (1980) -one of the primary resources on metaphors- through metaphors, it is possible to reconfigure abstract nouns with clearly understandable concrete words. Yildirim and Simsek (2005) use "figure of speech" to address metaphors. As for the wordplays, it can be maintained that imagery through wordplays appears mostly as slogans in advertisements and posters.

Yavuzer (2005) suggests that pictures are easier ways of explaining things to children with limited vocabulary repertoire. In this regard, pictures ensure their connection with the outside world. Children reflect a part of their self through pictures; and utter their feelings, ideas and views with paintings (Yavuzer, 2005). Platten (1995) maintains that urging young students to define a concept is a wrong way of evaluating their knowledge about that concept (cited in Cin, 2004). Therefore, the current research analyzed children's perception of the Internet through their paintings rather than asking them the pure definition of it. 
There are similar studies in literature, but to our knowledge, none addressed the Internet concept. The Cin (2004) study, asked the sea concept to 50 students who had just started primary education and to a group of seven year olds. Their perception about the concept was analyzed through a semi-configured interview form, picture recognition and drawing techniques. In another study by Tas, Aslan and Sayek (2006) children's perception about being a doctor was analyzed through addressing their paintings about this concept. Saban, Kocbeker and Saban (2006) studied with teacher candidates to determine their perception about the teacher concept. They also resorted to metaphors, and asked participants to complete the sentence: "Teacher is like ...., because ...." Nuhoglu and Afacan (2007) evaluated primary students' ideas about scientists by asking them to draw a picture and responding to open ended questions. Similarly, Yurtal and Artut (2007) examined the perception forms of children about violence through analyzing their pictures, and asking them to define their paintings as well.

The current study aimed to investigate the $5^{\text {th }}, 6^{\text {th }}$ and $7^{\text {th }}$ graders perceptions of the Internet through examining paintings they produced. Following sub-purposes were addressed within this framework:

- What are the general characteristics of the students in terms of their Internet access?

- How did the $5^{\text {th }}, 6^{\text {th }}$ and $7^{\text {th }}$ graders imagine the Internet concept?

- Was there any relationship with the images they produced and the Internet use purposes?

- Was there any relationship with the images they produced and the objects which came to their mind first about the Internet?

- Was there any connection with the age range and their Internet access intentions?

\section{Methods and Procedures}

The $5^{\text {th }}, 6^{\text {th }}$ and $7^{\text {th }}$ graders of 26 Haziran Primary School in Tokat constituted the research context. The painting teacher contributed to the current study through asking his students to draw pictures about the "Internet" concept. The objective in the current study was not generalization for other groups, but examining the imagery of the present situation as a complete picture. Within this research, 65 students drew pictures: $19(29.2 \%)$ were $5^{\text {th }}$ graders, $26(40 \%)$ were $6^{\text {th }}$ graders and $20(30.8 \%)$ were $7^{\text {th }}$ graders. The age of the students ranged from 11 through 14 ( $\bar{X}=12.25$; SD = 0.96). These students could be considered as moving from the concrete operational stage to the formal operational stage as defined by Piaget in his theory of cognitive development (Charles, 1992). Piaget proposed that explanations characterized by proper use of logic get more abundant around the ages of 11 and 12, and these play an important role in children's thoughts.

Students completed their pictures at home in order to prevent mutual influence from peers' work. As the participation was voluntary, it was assumed that everyone painted their own picture without outside help. Each student used their own materials and preferred drawing technique (watercolor, gouache, pastel crayons, pencils, felt tip, etc.). In addition, voluntary students were given a 10-item survey form, and demographic information was collected. The form included a list of items such as grade, gender and age; whether they had a computer at home, if so whether they 
used the Internet; if they used the Internet, how often they used it; when they used the Internet and the most common purposes of using the Internet. Students were also asked to provide three objects which came to their mind about the 'Internet'. Verbal permission of the painting teacher was asked for the study. The data collected has not been used anywhere else except for the current study.

The demographic data have been analyzed through SPSS 11.0. Frequency, percentage and chisquare analyses were carried out. To analyze the paintings drawn, a one-hour lecture was taken from an expert in the field of painting education, and three pictures were analyzed with a professional. At the end of the analysis process, another meeting was carried out with the expert and the approval of five randomly selected pictures was realized. Coding work was completed in accordance with the themes and concepts emerging from the paintings. Then, an evaluation graph was prepared. Qualitative data were analyzed through content analysis.

The structural validity was attempted through describing the processes carried out in detail and storing the documents in an electronic medium; the internal validity was aimed through using more than one data type (picture and survey form); external validity was realized through giving plausible examples of findings; and reliability was sustained through making analytical generalizations addressing the research results in the literature.

\section{Findings}

The findings and their corresponding interpretations were provided alternately to sustain semantic unity. Table 1 summarized the general characteristics of the participants, including whether they had computer/Internet at home as well as the frequencies and purposes of usage.

Table 1. Characteristics of the participants ${ }^{*}$

\begin{tabular}{llrr}
\hline Variable & & $f$ & $\%$ \\
\hline Do you have a PC at home? & Yes & 31 & 47.7 \\
& No & 34 & 52.3 \\
\hline Does your PC have an Internet connection? & Yes & 20 & 64.5 \\
& No & 11 & 35.5 \\
\hline Can you use the Internet? & Yes & 58 & 89.2 \\
& No & 7 & 10.8 \\
\hline How often do you use the Internet? & Everyday & 6 & 9.5 \\
& Few times a week & 40 & 63.5 \\
& Few times a month & 8 & 12.7 \\
& Few times a year & - & - \\
\hline Where do you use the Internet the most? & Never & 9 & 14.3 \\
\hline & Home & 17 & 27 \\
& School & 28 & 44.4
\end{tabular}




\begin{tabular}{llrr} 
& $\begin{array}{l}\text { A friend's house } \\
\text { Internet café } \\
\text { Other (neighbor-kin's } \\
\text { house, father's } \\
\text { company) }\end{array}$ & 5 & 7.9 \\
& E-mail & 6 & 9.6 \\
\hline $\begin{array}{l}\text { For which purposes do you use the Internet the } \\
\text { most? }\end{array}$ & Chat & 1 & 1.6 \\
& Game & - & - \\
& Assignment & 9 & 13.8 \\
\hline
\end{tabular}

"Missing values are not shown in the table.

Sixty five of the pictures that students drew were analyzed. In 36 of them a Google image was present. Hence, it was possible to suggest that students identified the Internet concept with Google. The reason for this could be that Google was among the most visited web sites both around the world and in Turkey (ALEXA, 2008). The www image was found in 37 paintings. Thus, most of the students knew about the entrance key of the World Wide Web. Within paintings, there were only 12 images concerning e-mail or MSN programs. In this regard, one could imply that most of the students did not have an e-mail account and even if they did, they seemed to use it rarely. While the number of the desktop PCs was 88 in the paintings, there were only 3 laptops. There was only one image of a cell phone within the paintings. It could be suggested that students were not using wireless connection, and that they connected to the net mostly through desktop PCs. In 15 paintings, web cams, microphones and loudspeakers were given as additional hardware. This suggested that students sometimes chose the Internet for sound and video connections. Students draw desktops with different windows (Pictures 4, 7 and 8). There were a total of 91 desktops or window images. When analyzed with regard to the place, 25 rooms, 5 Internet cafés, a computer lab, 2 libraries, 13 desktops and 26 backgrounds could be observed. Students depicted themselves in 43 paintings, and described other people in 12 paintings. In terms of the messages conveyed, 31 of the paintings involved positive messages whereas 10 paintings had negative messages. In addition, students made certain comparisons and contrasts like benefits/deficits of the Internet as well as the good/bad aspects of the Internet in 23 paintings. While there were warm colors dominant in 59 paintings, only 3 paintings contained cool colors.

Images generated by the $5^{\text {th }}, 6^{\text {th }}$ and $7^{\text {th }}$ graders about the Internet concept were given in Table 2 . Through such images, we could comment on how students perceived the Internet. First three images concerning the Internet concept were game (32 students), assignment or homework (26 students) and chat (16 students). When the purpose of using the Internet was asked (see Table 1), assignment or homework was in the first place with a ratio of 84.6 percent ( 55 students). In a previous research carried out by Ersoy and Yasar (2003), more than half of the participants considered homework as the purpose of using the Internet. Game was in the second place with a proportion of 13.8 percent (9 students). In a research carried out in Information Networks Statistical Research (2002) among 17.000 students aged 6 to 17, it was indicated that the children used the Internet for gaming, e-mail, information access and chat successively (cited in Orhan \& Akkoyunlu, 2004). In the Orhan and Akkoyunlu study, e-mail and chat were in the first place; game ranked the second, and accessing information for assignments was in the third place. A research in 
England revealed that a quarter of the children aged 7 to 16 year-old connected to the Internet constantly and used the Internet heavily to find material for their assignments and school projects (Thompson, 1999). Another study revealed that students used the Internet primarily for entertainment purposes and they did not get enough support from their parents and teachers (Ersoy \& Yasar, 2003). The fact that children are fed emotionally, socially, mentally and physically through games (Orhan \& Akkoyunlu, 2004), teachers should search games which are suitable for children's age and guide their parents accordingly, so that children can improve problem solving abilities. There was not any chat image in the recorded purposes of children's Internet access. In brief, students presented their expressions regarding the purpose of their Internet connection through their imagery.

Table 2: Images concerning the Internet concept

\begin{tabular}{lc}
\hline Images & $f$ \\
\hline Game & 32 \\
Homework & 26 \\
Chat & 16 \\
Research & 11 \\
Music & 8 \\
Video & 6 \\
Flower, butterfly, tree & 5 \\
World & 5 \\
Violence & 5 \\
News & 4 \\
Picture & 4 \\
Monster, fly, wolf & 3 \\
Bad Habits & 3 \\
Banking & 2 \\
Individualism & 2 \\
Motionlessness & 2 \\
Torch, candle & 2 \\
Sport & 2 \\
Library & 3 \\
Shopping & 1 \\
Printer & 1 \\
Makes distant near & 1 \\
Guide negatively & 1 \\
Saves time & \\
\hline
\end{tabular}

Table 3: The first three things which come to their mind about the Internet

\begin{tabular}{lrr}
\hline Purposes & $f$ & 1st line \\
\hline Homework & 57 & 35 \\
Game & 45 & 20 \\
Chat & 23 & 1 \\
Research & 18 & 5 \\
Music & 12 & \\
Entertainment & 6 & \\
News & 3 & 1 \\
Help & 3 & \\
Actual information & 2 & 2 \\
Communication & 2 & \\
E-mail & 1 & 1 \\
Education & 1 & \\
\hline
\end{tabular}

There appeared to be a connection between the images produced and the three things which come to their mind about the Internet. While the first three dominant images related to the Internet concept in the paintings were game (32 students), homework (26 students) and chat (16 students), the three things that come to their mind first about the Internet were homework (57 students), game (45 students) and chat (23 students). When Table 2 and Table 3 were comparatively analyzed, search (18 students) and music (12 students) seemed to follow a similar path. In this regard, the limitation of the current study -painting at home- seemed to be 
suppressed as findings suggested that the students painted images themselves without any help from others.

The students' purpose of the Internet access varied according to their age $\left(X^{2}{ }_{(2)}=9.87 ; p=.02\right)$. As their age increased their usage of the Internet for gaming decreased, and their homework related Internet usage increased. Similar findings were obtained in the Orhan and Akkoyunlu (2004) research. Findings revealed that when the age increased, "game" related Internet usage declined and "accessing information" increased.

Table 4: Participants' Internet usage purposes according to their age

\begin{tabular}{ccccccc}
\hline & & Age 11 & Age 12 & Age 13 & Age 14 & Total \\
\hline Game & $f$ & 6 & 1 & 1 & 1 & 9 \\
& $\%$ & $66.7 \%$ & $11.1 \%$ & $11.1 \%$ & $11.1 \%$ & \\
Homework & $f$ & 10 & 21 & 17 & 6 & 54 \\
& $\%$ & $18.5 \%$ & $38.9 \%$ & $31.5 \%$ & $11.1 \%$ & \\
\hline Total & $\mathrm{f}$ & 16 & 22 & 18 & 7 & 63 \\
\hline
\end{tabular}

Students seemed to express themselves in a more detailed way in their paintings, and the paintings contained some obscure elements. In this regard, some paintings were specifically chosen as examples. "Google" images in the pictures were on the foreground. Students inserted some notes and attached some keywords to their pictures. For instance, in Picture 1 a 12 -year-old girl who did not have a computer compared "Google" with a tree having various categories on its branches.

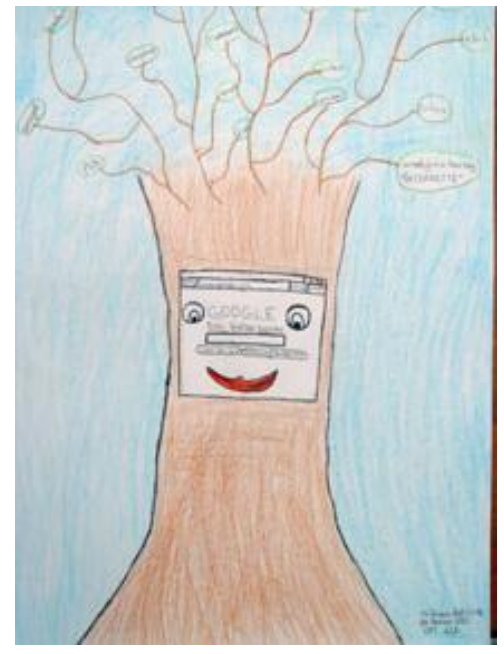

Picture 1. Girl, 12, with no computer

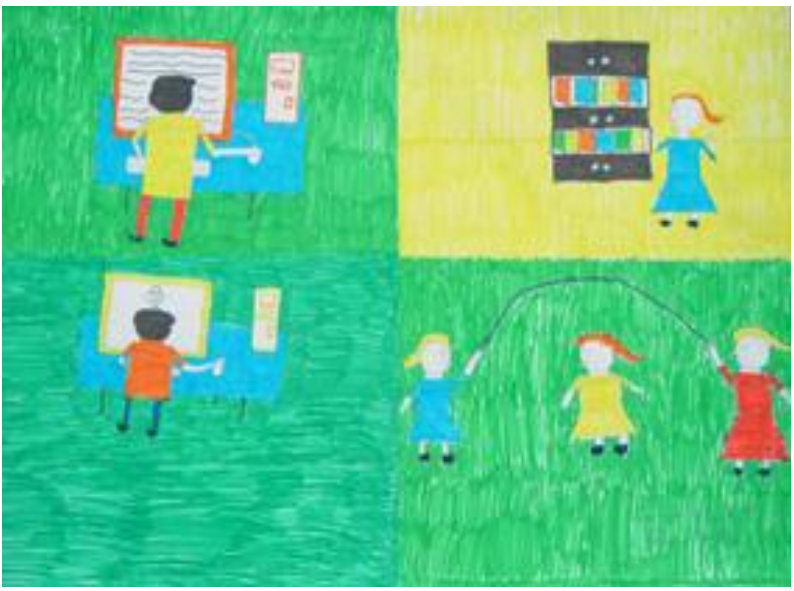

Picture 2. Girl, 12, with no computer

In Picture 2, a comparison appeared. This comparison could be interpreted either as "the computer owners vs. others" or "girls vs. Boys". The one who had a computer could reach information while sitting still, whereas the other who did not have a computer went to the library. The one who had a computer played computer games at home alone, whereas the other who did 
not have a computer played outside with others. Interestingly the comparison addressed a gender perception as well. In the figures drawn (girls as wearing skirts, having long hair; boys having short hair, wearing pants), it could be suggested that the girls did not have a computer and the boys did. In society, there is a prevalent opinion that men are more predisposed to technical subjects. This painting could be considered as conveying gender differences. It might also be thought that the picture might have been painted by an individual grown up according to strict gender rules of a traditional society. In patriarchal societies, views about the priority of men might emerge in all kind of subjects which emerged here in terms of using computers.

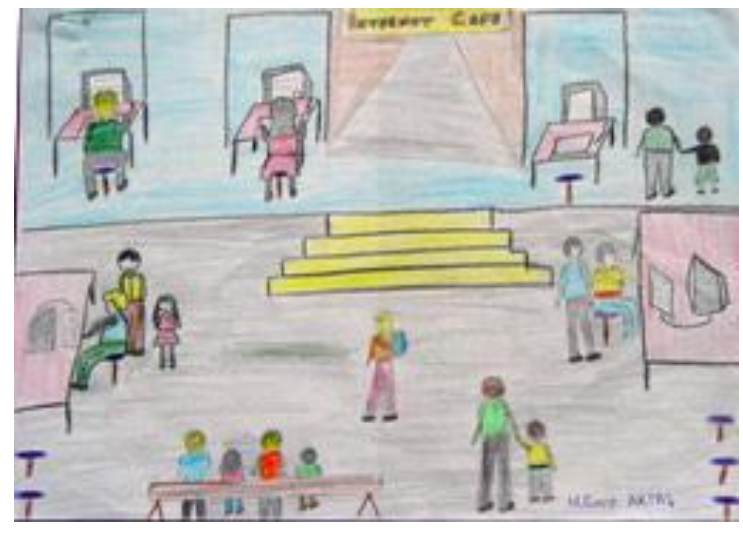

Picture 3. Boy, 12, with no computer

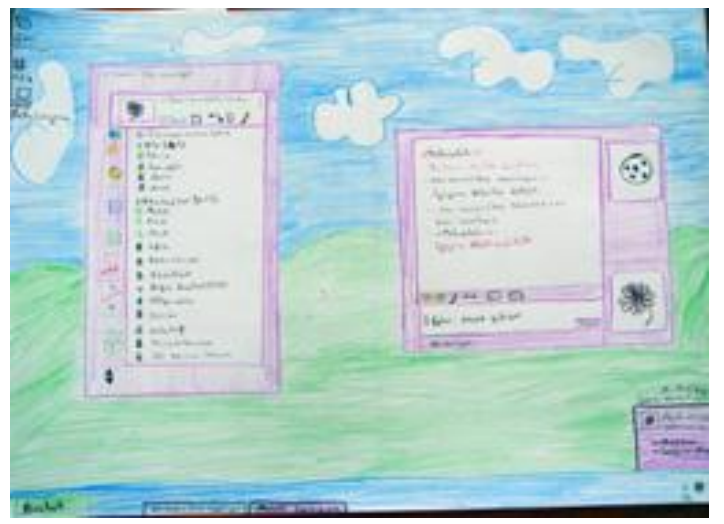

Picture 4. Boy, 13, has computer and Internet connection

When Picture 3 was analyzed, it was possible to state that this 12 year old boy who did not have a computer went to the Internet café for Internet access. The Internet cafés, being primary places of serving the Internet needs of a huge part of the society, have taken over a special mission to help us become an information society (Taspinar \& Gumus, 2005). The abundance of people in the painting was noteworthy. On the other hand, the depiction of the parents with little children suggested that they were aware of the fact that those under the age of 12 could only enter Internet cafés with written permission or with their parents. For negative situations, frequent and meticulous control of these places seems necessary. According to the Taspinar and Gumus (2005) study, the establishment of standards for Internet cafés would contribute to the usage of these places for educational purposes.

In Picture 4, the apparent element was the direct depiction of a desktop. There was a portrayal of chatting action through a commonly used instant messaging tool, MSN Messenger ${ }^{\mathrm{TM}}$. This student put his own portrait, and shared his personal contact list and user name on the picture. Remarkable details on such a depiction suggested that this individual used Internet mostly for the purpose of conversation.

Pictures 5 and 6 were painted by two students who had computers, but no Internet connection. The common object in both pictures was the "earth". Picture 5 , as a scheme mostly found in many books, implied that the Internet connected different computers to each other and was a huge network, which surrounded the earth with a series of connection protocols (Altun, 2003). 


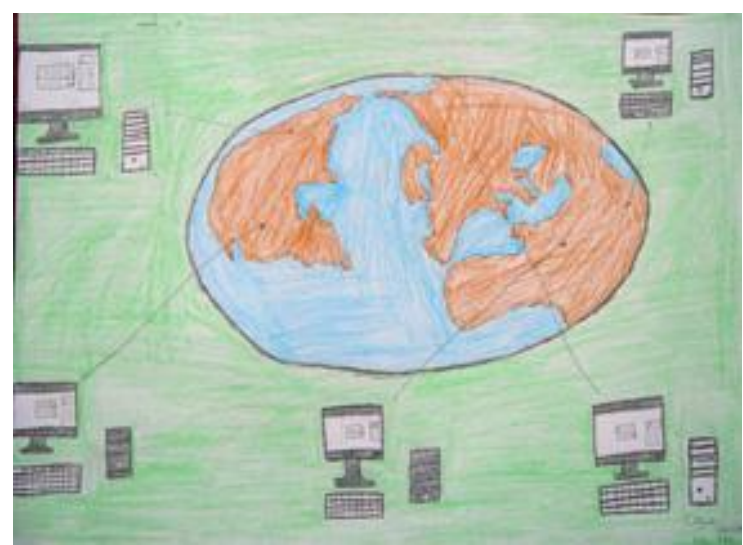

Picture 5. Boy, 13, has computer, no Internet connection

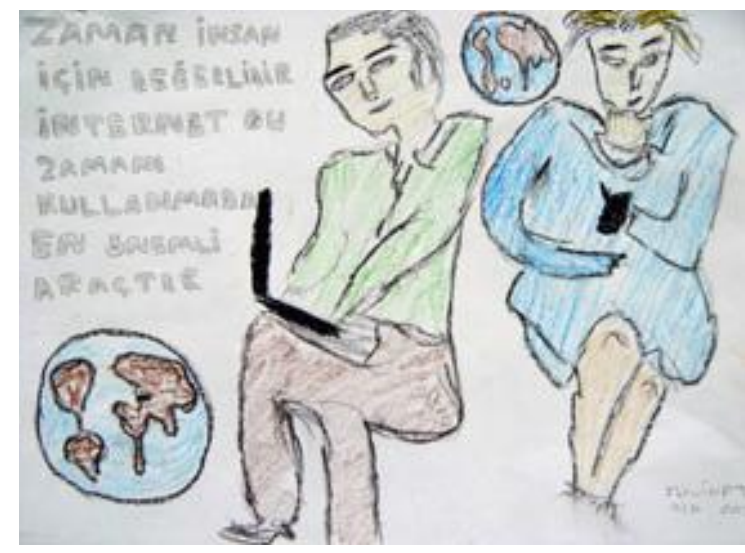

Picture 6. Girl, 14, has computer, no Internet connection

In Picture 6, a 14 year-old girl approached the Internet with a different perspective: the wireless connection. Both the notebook computer and the cell phone were remarkable elements of the picture. Throughout the analysis of all 65 pictures in this survey, only this painting addressed the quality of connecting to the Internet via cell phone. The woman who had a cell phone in her hand and the earth behind her symbolized this feature. Along with the visual elements, the student tried to express herself by writing and mentioning the important benefits of the Internet to save time.

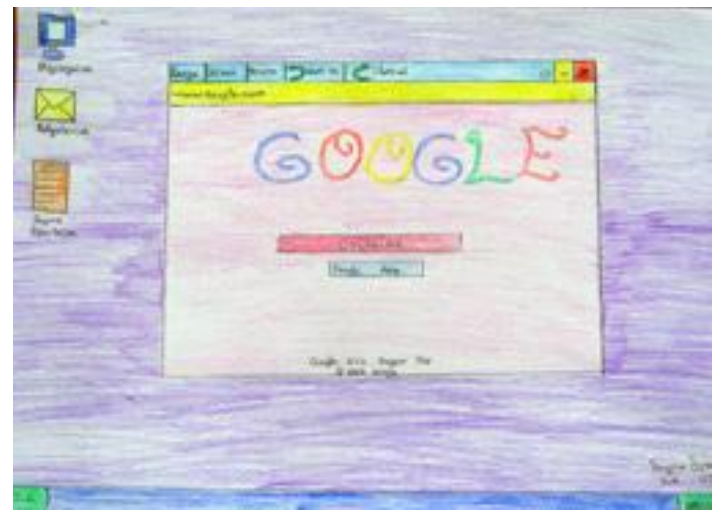

Picture 7. Girl, 13, has computer and Internet connection

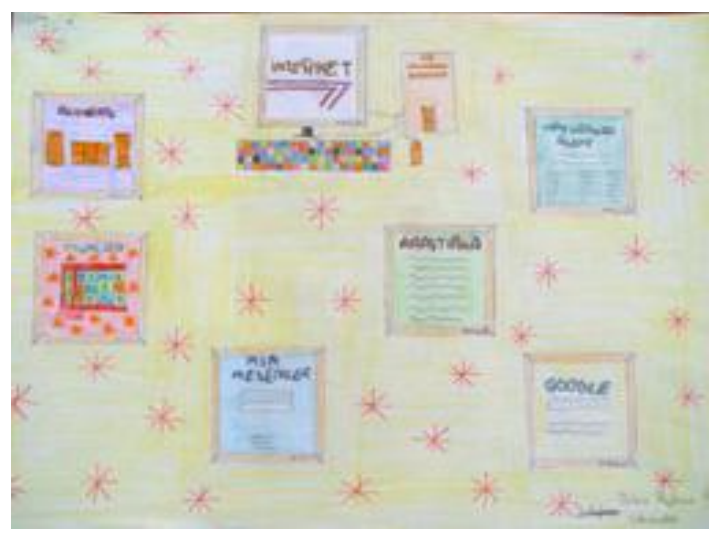

Picture 8. Girl, 12, has computer and Internet connection

Just like Picture 4, Picture 7 also depicted a portrait of the desktop of a girl who had a computer and Internet connection. However, there was a personal folder named "my assignments". In Picture 8, there were several desktops (illustrating shopping, research, MSN Messenger ${ }^{\mathrm{TM}}$, animal world, "oyuncan [gameboy]" and Google). Among 65 paintings analyzed, girls choose to portray the websites of their preferred popular figures such as Barbie, Selena, Group Hepsi, Kenan Dogulu; whereas boys choose to depict web sites like "kraloyun" and "oyuncan" (i.e. both focusing on gaming), "bombabomba" (i.e. a popular star website) and sports. 
In addition to these depictions, the Internet week celebrations, games including violence, car races and homework studies (trees, Ziya Gokalp, etc.) were observed. In a study by Akgunduz, Oral and Avanoglu (2006), individuals in the 12 to 26 age category choose war games, and this preference decreased as their age increased. In a painting, a game playing individual was portrayed with a speech bubble on his head showing his ideas about his need to study. Some comparative paintings put forward the benefits and harms of the Internet (positive and negative sides). A painting compared the Internet with a burning candle. In another one, there was a conversation between a mother who had a married daughter living in another city and her neighbor. The mother was telling her about the opportunity to talk with her daughter thanks to the "Internet".

\section{Conclusions and Recommendations}

Information literacy abilities are considered as a necessity for information, and help individuals to reach information sources when needed. More specifically, using the information and sharing it effectively are among the abilities we aim to equip students with during the learning-teaching process (Akkoyunlu \& Yilmaz, 2005). Schools and families are struggling for the generation of such individuals. However, along with the family and the school, the environment has an influence on the individual as well. In the current study, it seemed that the individuals were aware of the images surrounding them, and they depicted these to a considerable extent. The fact that gradually digitalizing mediums could pollute these images, studies concerning the distribution of the optimal context should be given more emphasis. In addition proper context models that are suitable for semantic structure and for the characteristics of an individual's growth and learning should be provided.

Students in the current study seemed familiar with the Internet concept. In addition, using paintings for data collection turned out to be an effective and a versatile method. Indeed, Picasso's saying "Painting is just another way of keeping a diary" encouraged us about this study and has proved right. The students reflected their inner worlds, their selves and perceptions in their paintings sincerely, and put forward their mental images. Resorting to implications of the current picture, following suggestions could be posed. First of all, obtained images should be written in sentences as well, and a discussion form should be generated so that the perceptions of primary school students concerning the Internet can be written down in detail. Second, the students should be trained about the aims of the Internet usage (e.g. game, assignment, chat) and it should be ensured that they use the Internet consciously and in accordance with the ethic codes. Third, teachers and parents should collaborate and work jointly in order for students to obtain maximum benefits from the Internet. Finally, Internet cafés should be transformed into respectable places where children can make use of Internet with ease and effectiveness.

\section{References}

Akgunduz, H., Oral, B., \& Avanoglu, Y. (2006). Bilgisayar oyunlari ve Internet sitelerinde sanal siddet ogelerinin degerlendirilmesi [Computer games and the evaluation of fictitious virtual violence elements in Internet sites]. Milli Egitim, 171, 67-82. 
Akkoyunlu, B., \& Yilmaz, M. (2005). Ogretmen adaylarinin bilgi okuryazarlik duzeyleri ile Internet kullanim sikliklari ve Internet kullanim amacları [Prospective teachers' ınformation literacy level, Internet usage frequencies and purposes of their Internet usage]. Eurasian Journal of Educational Research, 19, 1-14.

ALEXA, (2008). The Web Information Company, Alexa Web Search Top 500, Retrieved November 28, 2008 from http://www.alexa.com/site/ds/top_500

Altun, A. (2003). Ogretmen adaylarinin Internet'e yonelik tutumlari [Prospective teachers' attitudes toward Internet]. Education and Science, 28 (127), 3-9.

Arnett, R. C. (1999). Metaphorical guidance: Administration as building and renovation. Journal of Educational Administration, 37 (1), 80-89.

Birch, T. (2008). Introduction to mental images. Retrieved November 28, 2008 from http://www.gis.net/ tbirch/hp5.html

Burnett, R. (2007). Imgeler nasıl dusunur [How images think, MIT Press. 2004]? İstanbul: Metis.

Cerit, Y. (2006). Ogrenci, ogretmen ve yoneticilerin okul kavramiyla ilgili metaforlara iliskin gorusleri [School Metaphors: The Views of Students, Teachers and Administrators]. Educational Sciences: Theory \& Practice (Kuram ve Uygulamada Egitim Bilimleri), 6(3), 669699.

Charles, C. M. (1992). Ogretmenler için Piaget ilkeleri [Piaget principles for teachers]. (Trans. Ulgen, G.). Belmont, California: Fearon.

Cin, M. (2004). Ilkokul 1. sınıf ogrencilerinin deniz kavramini algilamalari üzerine bir araştirma [An investigation of the conceptions of sea among primary school children]. Educational Sciences: Theory \& Practice (Kuram ve Uygulamada Egitim Bilimleri), 4(1), 7-23.

Ersoy, A., \& Yasar, S. (2003). Ilkogretim 4. ve 5. sınıf ogrencilerinin Internet kullanma durumlari [The Internet use situations of elementary students of $4^{\text {th }}$ and $5^{\text {th }}$ grades]. Turk Egitim Bilimleri Dergisi, 1 (4), 401-425.

Forrester, M. A. (2000). Psychology of the image. London, UK: Routledge. Retrieved November 28, 2008 from http://site.ebrary.com/lib/hacettepe/Doc?id=10054201\&ppg=10

Lakoff, G., \& Johnson, M. (1980). Metaphors we live by. Chicago: University of Chicago Press.

Nuhoglu, H., \& Afacan, Ö. (2007). Ilkogretim ogrencilerinin bilim insanına yonelik dusuncelerinin degerlendirilmesi [Evaluation of primary school children's thoughts about science-man]. $16^{\text {th }}$ National Educational Sciences Conference, Gaziosmanpaşa University, Faculty of Education, 5 -7 September, Tokat, Turkey.

Orhan, F., \& Akkoyunlu, B. (2004). Ilkogretim ogrencilerinin Internet kullanimları uzerine bir arastirma [A study on the use of Internet by primary school students]. Hacettepe Universitesi Egitim Fakultesi Dergisi, 26, 107-116.

Oxford, R., Tomlinson, S., Barcelos, A., Harrington, C., Lavine, R., \& Saleh, A. (1998). Clashing metaphors about classroom teachers: Toward a systematic typology for the language teaching field. System, 26, 3-50. 
Saban, A., Kocbeker, B. N., \& Saban, A. (2006). Ogretmen adaylarinin ogretmen kavramina iliskin algilarinin metafor analizi yoluyla incelenmesi [An investigation of the concept of the teacher among prospective teachers through metaphor analysis]. Educational Sciences: Theory \& Practice (Kuram ve Uygulamada Egitim Bilimleri), 6(2), 461-522.

SPSS Inc. (2001), SPSS For Windows (Version 11.0.0) [Computer application]. Chicago, IL: SPSS Inc.

Tas, Y., Aslan, D., \& Sayek, í. (2006). Doktorluk meslegini çocuklar resimlerine nasıl yansitiyorlar? 712 yas grubu çocuklar arasinda yapilmis bir ornek [How children reflects "doctors" to pictures they drawn? A case study of children between 7 and 12 years]. Surekli Tip Egitimi Dergisi, 15(11), 184-191.

Taspinar, M., \& Gumus, C. (2005). Internet kafelerin guvenlik baglamında degerlendirilmesi [Investigating Internet cafes in the context of security]. Polis Bilimleri Dergisi, 7(1), 77-95.

Thompson, B. (1999). New kids on the net. The Guardian, 24th June.

Wikipedia, (2008). Imagery, Retrieved November 28, 2008 from http://en.wikipedia.org/wiki/Imagery

Yavuzer, H. (2005). Resimleriyle cocuk [Identifying child with his/her pictures]. Istanbul: Remzi Kitabevi.

Yildirim, A. \& Simsek, H. (2005). Sosyal bilimlerde nitel arastırma yontemleri [Qualitative research methods in social sciences]. Ankara: Seckin.

Yurtal, F., \& Artut, K. (2007). Çocuklarin siddeti algilama bicimlerinin cizdikleri resimlere yansimalari [Reflections on the pictures that children drawn about how they perceive "violence"]. $16^{\text {th }}$ National Conference on Educational Sciences, Gaziosmanpaşa University, Faculty of Education, September 5-7, Tokat, Turkey.

Correspondence: Necmi Esgi, Assistant Professor, Department of Computer Education and Instructional Technologies, Faculty of Education, Gaziosmanpasa University, Tokat, Turkey 